\title{
Utilization of Plastic waste for Making Plastic Bricks
}

\author{
R. S. Kognole1, Kiran Shipkule², Manish Patil², Lokesh Patil², Udaysinh Survase ${ }^{2}$ \\ ${ }^{1}$ M.Tech (Hydraulics), ${ }^{2}$ B.E.Civil \\ 1,2Tssm's BSCOER, Narhe, Pune, Maharashtra, India
}

\begin{abstract}
How to cite this paper: R. S. Kognole | Kiran Shipkule | Kiran Shipkule | Manish Patil | Lokesh Patil | Udaysinh Survase "Utilization of Plastic waste for Making Plastic Bricks" Published in International Journal of Trend in Scientific Research and Development (ijtsrd), ISSN: 24566470, Volume-3 | Issue-4, June 2019, pp.878-880, URL: https://www.ijtsrd.c om/papers/ijtsrd23 938.pdf

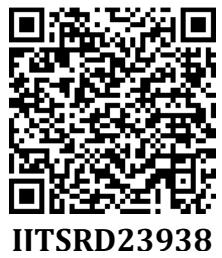

Copyright (C) 2019 by author(s) and International Journal of Trend in Scientific Research and Development Journal. This is an Open Access article distributed under the terms of the Creative Commons

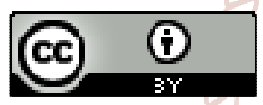
Attribution License (CC BY 4.0) (http://creativecommons.org/licenses/ by $/ 4.0$ )

These gases effect on the human health and also living animals. Human suffers by the toxic gases such as cancer, high blood pressure, Asthma.etc We are not completely able to stop the use of plastic but we are able to recycle and reuse it by many ways and minimum effect on environment. We use such recycle plastic in the various industries such as construction, transportation, manufacturing etc. In construction industry, larger cost of project is include in materials up to $60 \%$ to $70 \%$ of the total cost of the project. So, construction industry large amount of bricks are used and they available in various forms such as clay bricks, concrete bricks, fly ash bricks and foam bricks. In this project, we try to use wastes plastic to manufacture the bricks and increase the strength and achieve economy so the people can easily afford this type of bricks.

\section{Literature Review}

Due to increasing population, the demand of plastic materials and necessary requirement also increases. Brick is largest materials used in the construction industries and occupied in very large amount of materials of the project especially in residential projects. We use various types of plastic with various combinations to produce different type of bricks. We find the different properties of bricks by conducting various tests on it. Among them compression and water absorption test is most common test conducted on bricks by the various researches. But the use of such types of bricks is very limited in the industry. We need to convenience the people to use the such types of bricks and increase the use of it.

1. CRITICAL REVIEW ON TYPES OF BRICKS TYPE 14: PLASTIC SAND BRICKS : 1)MANISH KUMAR SAHU, 2)LOKESH SINGH: Volume- 5, Issue-11, Nov.-2017):Brick is one of the most common masonry units used as building material. Due to the demand, different types of waste have been investigated to be incorporated into the bricks. There has been a considerable imbalance between the availability of conventional building materials and their demand in the recent past. On the other hand the plastic waste is abundantly available and the disposal of waste plastics is a biggest challenge, as repeated recycling of PET bottles poses a potential danger of being transformed to a toxic material and only a small proportion of plastic wastes are being recycled. Because of costly conventional recycling techniques, there has been an increased demand for more scientific and innovative technologies to effectively recycle these materials. This paper deals with recycling and manufacturing process, materials used as well as the testing method of plastic sand bricks.

2. Manufacturing And Testing Of Plastic Sand Bricks1) Mr. N. Thirugnanasambantham, 2)P. Tharu nKumar, 3) R.Sujithra, 4)R. Selvaraman, 5) P. Bharat hi:- Plastic is a non-bio-degradable substance which takes thousands of years to decompose that creates land as well as water 
pollution to the environment. The quantity of plastic waste in Municipal Solid Waste (MSW) is expanding rapidly. It is estimated that the rate of usage is double for every 10 years. The Plastic usage is large in consumption and one of the largest plastic wastes is polyethylene (PE). The utilization of earth based clay material resulted in resource depletion and environmental degradation. As amount of clay required for brick is huge, in this project these waste plastics are effectively utilized in order to reduce the land space required to dump these wastes. This creates the prevention from various harmful diseases. Polyethylene (PE) bags are cleaned and added with fine aggregate at various ratios to obtain high strength bricks that possess thermal and sound insulation properties. This is one of the best ways to avoid the accumulation of plastic waste. It also helps to conserve energy, reduce the overall cost of construction and hence in this project, an attempt is made to manufacture the plastic sand bricks by utilizing the waste plastics.

\section{Objectives}

$>$ To develop an efficient way and to effectively utilize the waste plastics.

$>$ To reduce the consumption of natural resources such as clay for the manufacturing of bricks.

$>$ To minimize and reuse generation of waste plastic on the land and water to avoid land and water degradation and consequent pollution hazard.

$>$ To produce cost-effective materials which a common person can afford easily.

$>$ To reduce the plastic in waste streams saving nonrenewable resources.

\section{Methodology}

First, we need to collect the plastic waste and separate it from other wastes. Second, we should dry the plastic waste if it is wet and has a content of moisture. We have to use dry plastic waste. Then, we crush the plastic waste in small particles. the small particles crush into fine size particles. Fine particles of plastic waste also heated on a furnace (Bhatti) till it is in a liquid form. we add the stone dust into melt plastic. We can mix it properly and make a mix. We poured the mix into moulds. Keep it the mould for dry.

\subsection{USING DIFFERENT MATERIALS FOR PLASTIC BRICK-} Polythene

High density polymer (nylon66)

Plastic bottles (PET)

Plastic wastes

Plastic composite with other material

River sand(4.75mm)

Red soil

Cement

\subsection{DIFFERENT COMPOSITION WITH PLASTIC-}

Trial 1 - Some small samples -

Comp.1.Plastic Bottles Crush (50gm) + Red

Soil (50gm)

Comp.2.Plastic Bottles Crush (50gm) + River

Sand (50gm)

Comp.3.Plastic Bottles Crush (50g) + Stone

Crush (50gm)

Trial 2- Standard Size Bricks -

Comp.1 Plastic wastes crush $(0.750 \mathrm{~kg})+$ River

Sand (2.kg)

Comp.2 Plastic Wastes crush $(0.750 \mathrm{~kg})+$ Red soil(2.kg)

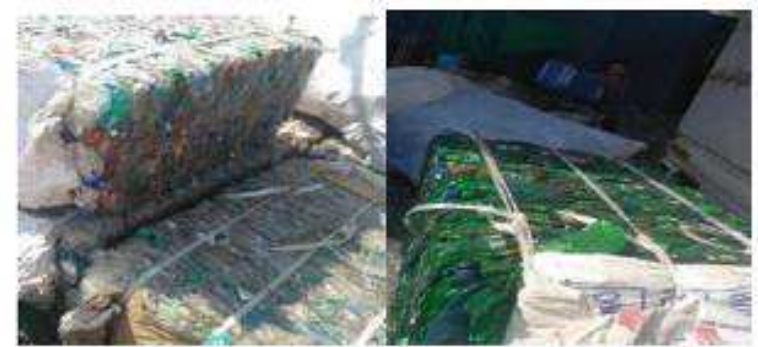

COLLECTION OF PLASTIC WASTE

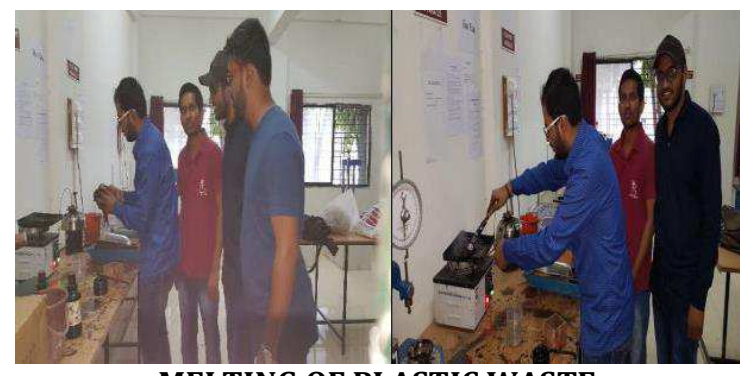

MELTING OF PLASTIC WASTE
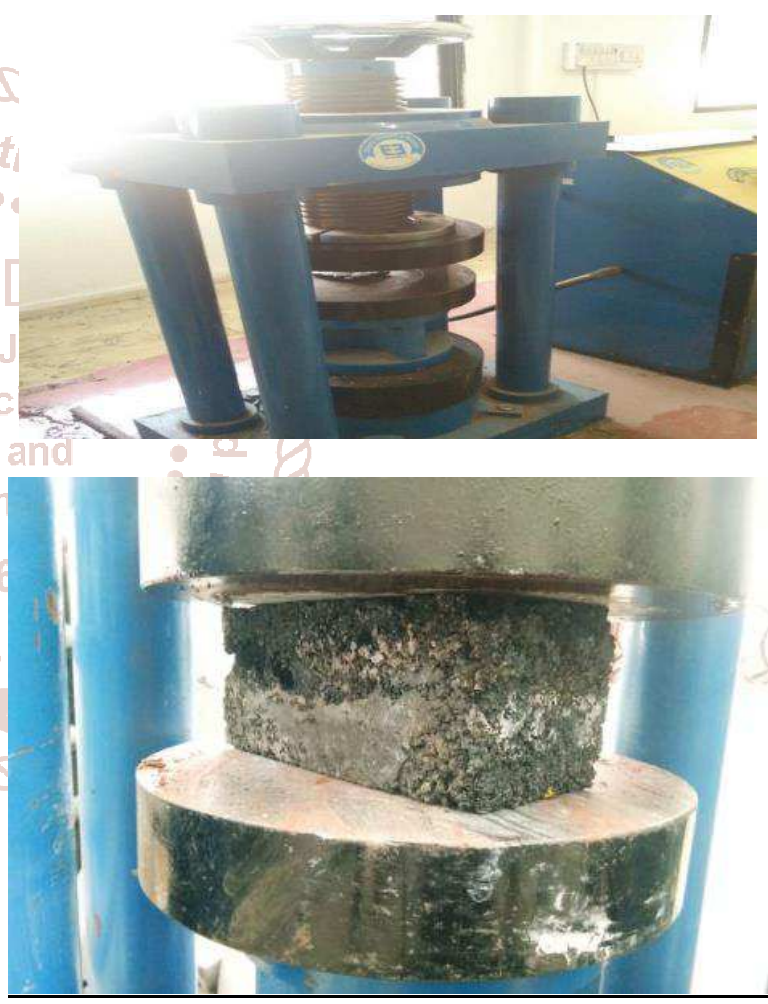

COMPRESSION TEST ON BRICK

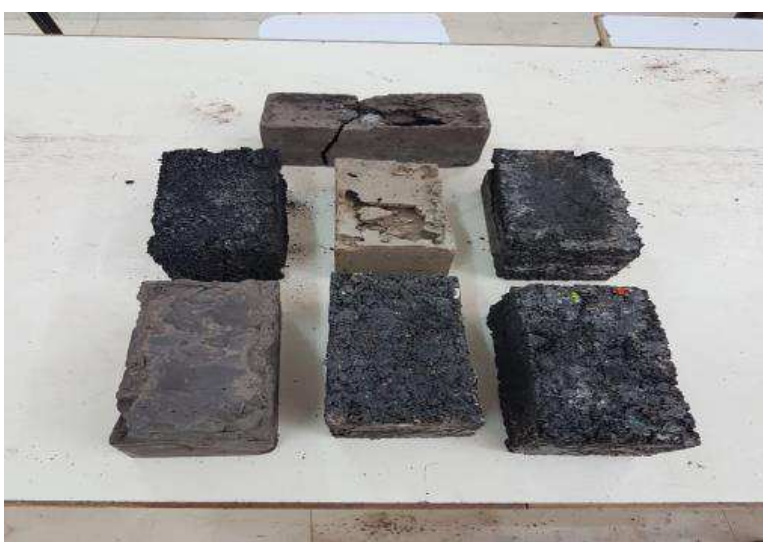

SECOND TRIAL BRICKS 
International Journal of Trend in Scientific Research and Development (IJTSRD) @ www.ijtsrd.com eISSN: 2456-6470

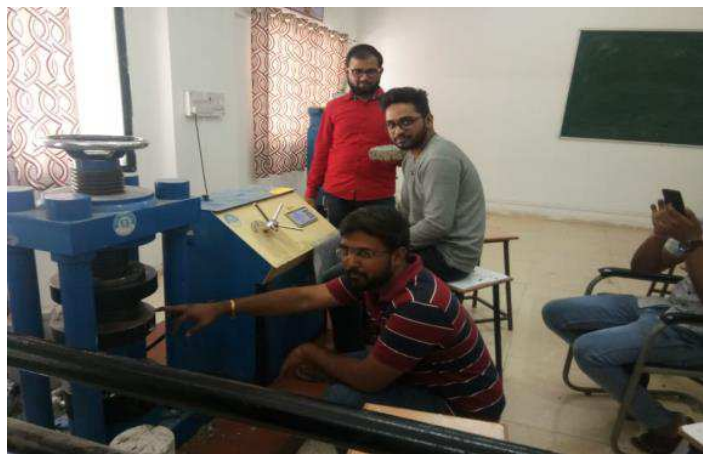

COMPRESSION TEST ON BRICK

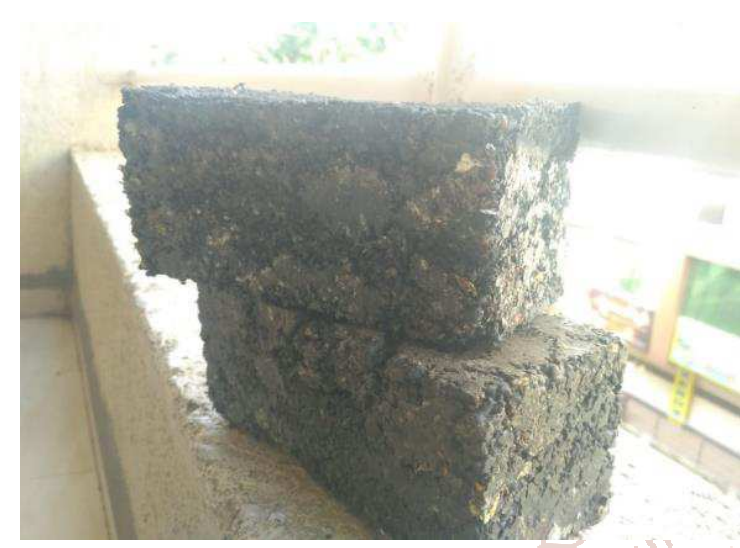

STANDARD BRICK AFTER REMOVING MOULD

LABORATORY TEST TRIAL 2

\begin{tabular}{|c|c|c|c|l|l|l|}
\hline COMP & COMPRESSION & $\begin{array}{c}\text { WATER } \\
\text { ABSORPTION }\end{array}$ & \multicolumn{1}{c|}{ SHAPE } & SOUNDNESS & DURABILITY & \multicolumn{1}{c|}{ HARDNESS } \\
\hline COMP1 & $97.50 \mathrm{KN}$ & $3 \%$ & $\begin{array}{l}\text { standardsize }(190 \\
\mathrm{mm} \times 90 \mathrm{~mm} \times 90 \\
\mathrm{~mm})\end{array}$ & $\begin{array}{l}\text { not ringing bell } \\
\text { sound and not } \\
\text { break }\end{array}$ & $\begin{array}{l}\text { Satisfied all } \\
\text { criteria of } \\
\text { durability }\end{array}$ & $\begin{array}{l}\text { there is satisfied } \\
\text { criteria of } \\
\text { hardness. }\end{array}$ \\
\hline COMP2 & $26 \mathrm{KN}$ & $\begin{array}{l}\text { Binding is not } \\
\text { properly so shape } \\
\text { not as per } \\
\text { standard size }\end{array}$ & $\begin{array}{l}\text { not ringing bell } \\
\text { sound and } \\
\text { break }\end{array}$ & $\begin{array}{l}\text { Saturation } \\
\text { affect the } \\
\text { durability }\end{array}$ & $\begin{array}{l}\text { There is } \\
\text { satisfied criteria } \\
\text { of hardness. }\end{array}$ \\
\hline
\end{tabular}

\section{Conclusion}

1. Waste plastic, which is available everywhere, may be put to an effective use in brick making. 2. Plastic sand bricks can help reduce the environmental pollution, thereby making the environment clean and healthy. 3. Plastic sand bricks reduce the usage of clay in making of bricks. 4. Plastic sand bricks give an alternative option of bricks to the customers on affordable rates. 5 . Water absorption of plastic sand brick is zero percent. 6 . We conclude that the plastic sand bricks are useful for the construction industry when we compare with Fly Ash bricks and 3rd class clay bricks.

\section{References}

[1] Dinesh S; Dinesh A; and Kirubhakaran K., "Utilisation of Waste Plastic in Manufacturing of Bricks and Paver
5. Result

Laboratory Test- Curing Test-

\begin{tabular}{|c|c|c|}
\hline SR. NO. & COMPOSITION & $\begin{array}{c}\text { WATER ABSORPTION } \\
\text { TEST (After 24 hr.) }\end{array}$ \\
\hline 1. & Comp.1. & 0 \\
\hline 2. & Comp.2. & 0 \\
\hline 3. & Comp.3. & 0 \\
\hline 4. & Red brick & $5 \%$ \\
\hline
\end{tabular}

COMPRESSION TESTSR. NO. COMPOSITION COMPRESSION(KN)

\begin{tabular}{|c|c|c|}
\hline 1. & Comp.1. & $15 \mathrm{KN}$ \\
\hline 2. & Comp. 2. & $10.5 \mathrm{KN}$ \\
\hline 3. & Comp.3. & $13.50 \mathrm{KN}$ \\
\hline 4. & Comp.4. & $15.50 \mathrm{KN}$ \\
\hline 5. & Red brick & $14 \mathrm{KN}$ \\
\hline
\end{tabular}

\section{Scientific

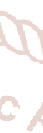

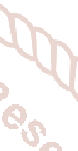

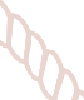

Blocks" International Journal of Applied Engineering Research, Vol.2 (4), pp. 364- 368.

[2] Nitin Goyal ; Manisha., "Constructing structures using eco-bricks", International Journal of Recent Trends in Engineering \& Research, Vol.2(4), pp. 159-164.

[3] Maneeth P D; Pramod K; Kishor Kumar; and Shanmukha Shetty., "Utilization of Waste Plastic in Manufacturing of Plastic-Soil Bricks" International Journal of Engineering Research \& Technology, Vol.3 (8), pp.529-536.

[4] Puttaraj M.H; Shanmukha S; NavaneethRai.P.G; and Prathima.T.B, "Utilization of Waste Plastic In Manufacturing of plastic-Soil Bricks" International Journal of Technology Enhancement and Emerging Engineering Research, Vol. 2(4), pp. 102-107. 